\title{
PREDIKSI NIAT PENGGUNAAN APLIKASI DAN PERMAINAN DARING FREEMIUM VERSI BERBAYAR DENGAN MENGGUNAKAN MODEL TPB
}

\author{
HARMANDA BERIMA PUTRA ${ }^{* 1}$ \\ NUNGKI PRADITA ${ }^{1}$ \\ KRISTINA ANINDITA HAYUNINGTIAS ${ }^{1}$ \\ ${ }^{1}$ PROGRAM STUDI AKUNTANSI, FAKULTAS EKONOMIKA DAN BISNIS, UNIVERSITAS STIKUBANK, \\ INDONESIA
}

\begin{abstract}
This study investigates how the Theory of Planned Behavior determines the customer intention to use the freemium paid version of online apps and games. Data were collected using an online questionnaire which is distributed to 189 students at several universities in Indonesia. Data were then analysed using structural equation modelling by Amos. The results show that the subjective norm has a positive effect on perceived behavioral control and attitude. Perceived behavioral control has a positive effect on intention. In addition, attitude did not have a significant effect on intention to use the freemium paid version of online apps and games.
\end{abstract}

Keywords: Freemium; Game Online; Intention; Theory Planned Behavior

\begin{abstract}
Abstrak
Studi ini menyelidiki bagaimana Theory of Planned Behavior menentukan niat pelanggan untuk menggunakan versi aplikasi dan game online berbayar freemium. Pengumpulan data dilakukan dengan menggunakan kuesioner online yang disebarkan kepada 189 mahasiswa di beberapa perguruan tinggi di Indonesia. Data kemudian dianalisis menggunakan pemodelan persamaan struktural oleh Amos. Hasil penelitian menunjukkan bahwa norma subjektif berpengaruh positif terhadap kontrol perilaku dan sikap persepsian. Kontrol perilaku yang dirasakan memiliki efek positif pada niat. Selain itu, sikap tidak berpengaruh signifikan terhadap niat menggunakan aplikasi dan game online versi berbayar freemium.
\end{abstract}

Kata Kunci: Freemium; Niat; Permainan Daring; Theory Planned Behavior

Article History: Received: (09-10-2020); Revised: (23-10-2020); and Published: (30-10-2020) Copyright $\odot 2020$ Harmanda Berima Putra, Nungki Pradita, Kristina Anindita Hayuningtias

How to cite this article: Putra, H.B., Pradita, N., dan Hayuningtias, K. A (2020). Prediksi Niat Penggunaan Aplikasi dan Permainan Daring Freemium Versi Berbayar Dengan Menggunakan Model TPB. Managament Insight: Jurnal IImiah Manajemen. 15(2), 130-143

Retrevied from: https://ejournal.unib.ac.id/index.php/Insight 


\section{PENDAHULUAN}

Dalam beberapa tahun belakangan ini, perkembangan ponsel pintar dan perangkat lunak dalam bentuk aplikasi dan permainan daring semakin meningkat. Hal ini terjadi karena adanya lonjakan permintaan pengguna ponsel pintar itu sendiri. Munculnya ponsel pintar, tablet, dan perkembangan teknologi lainnya seperti situs web, semakin membuka banyak peluang untuk menawarkan layanan digital kepada pelanggan (Hamari et al., 2017). Perkembangan ini telah mendorong beberapa perusahaan ponsel pintar dan perangkat lunak untuk melakukan ekspansi model bisnis baru dengan menciptakan perangkat lunak seperti permainan daring, buku elektronik, utilitas, platform jejaring sosial untuk memenuhi kebutuhan konsumen (Hsu et al., 2015).

Jika dilihat dari perkembangannya, banyak perusahaan layanan perangkat lunak daring yang telah berganti model bisnis yang sebelumnya menyediakan perangkat lunak berbayar berganti dengan menyediakan layanan dengan akses gratis, baik dalam bentuk aplikasi, maupun permainan. Diantaranya seperti, Youtube, Netflix, Google Docs, permainan daring seperti PUBG Mobile, atau aplikasi seperti pemutar musik Joox. Dalam industri teknologi, model bisnis seperti ini disebut dengan freemium. Sebagaimana Mäntymäki et al. (2020) yang mengatakan bahwa pada saat ini model bisnis freemium telah mendominasi dalam industri layanan perangkat lunak dalam bentuk konten digital seperti pemutar musik, video, surat kabar, serta layanan penyimpanan berbasis cloud, jejaring sosial, dan permainan daring.

Dalam dunia bisnis, perusahaan dituntut untuk dapat menyesuaikan layanan dengan perilaku konsumen. Menariknya, pada konteks freemium ini, konsumen dihadapkan dengan dua pilihan yang memiliki keuntungan masing-masing. Pertama, konsumen tetap dapat menggunakan layanan aplikasi maupun permainan secara gratis, tetapi memiliki keterbatasan dalam mengakses fiturnya. Kedua, untuk mendapatkan akses penuh, maka konsumen diminta untuk membayar paket yang telah disediakan. Dari dua kategori tersebut, terdapat dua fenomena perilaku konsumen yang perlu untuk diungkap lebih dalam, yaitu, apa yang membuat konsumen tetap bertahan menggunakan aplikasi dan permainan daring freemium versi tidak berbayar dan apa yang mendorong konsumen untuk menggunakan aplikasi dan permainan daring freemium versi berbayar.

Untuk mengetahui fenomena perilaku konsumen pada konteks penggunaan aplikasi dan permainan daring freemium ini, maka beberapa peneliti telah melakukan beberapa penelitian empiris (seperti Hamari et al., 2017; Hsu dan Lin, 2015; Ladeira et al., 2016). Hamari et al. (2017) dalam penelitiannya menguji pengaruh kualitas layanan yang dirasakan pada niat pelanggan untuk terus menggunakan layanan freemium dan membeli konten premium. Sedangkan, Ladeira et al. (2016) dalam penelitiannya menguji daya tarik visual hiburan, eskapisme, kesenangan, efisiensi, dan nilai ekonomi 
sebagai dimensi nilai pengalaman yang kemudian dapat mempengaruhi kesejahteraan anak setelah menggunakan permainan daring freemium. Lebih lanjut, Hsu dan Lin (2015) dalam penelitiannya menguji niat penggunaan aplikasi freemium dengan menggunakan model konfirmasi ekspektasi. Pada penelitian Hsu dan Lin (2015) ini, terdapat beberapa variabel yang dijadikan sebagai antesenden atau motif yang mendorong seseorang untuk membeli aplikasi freemium, seperti motif untuk menghilangkan iklan, motif kebiasaan, motif fungsionalitas, dan konten tambahan.

Berdasarkan beberapa penelitian tersebut, kami menyimpulkan bahwa terdapat kekurangan yang belum diungkap secara komprehensif mengenai anteseden dari individu itu sendiri dalam melihat perilaku penggunaan aplikasi atau permainan daring freemium (lihat Hamari et al., 2017; Hsu dan Lin, 2015; Ladeira et al., 2016). Padahal, terdapat beberapa alternatif yang dapat dijadikan anteseden dari perspektif individual ketika ingin melihat perilaku penggunaan aplikasi atau permainan daring freemium ini. Oleh karena itu, kami menyimpulkan bahwa diperlukan pendekatan yang lebih akurat untuk mengukur bagaimana perilaku konsumen dalam memutuskan menggunakan sebuah produk khususnya pada layanan freemium.

Terdapat beberapa pandangan ketika ingin melihat perilaku konsumen ketika menggunakan produk khususnya pada layanan freemium. Namun, dari beberapa model yang ada, Teori Perilaku Terencana atau disebut dengan TPB. TPB merupakan model yang paling representatif dalam melihat perilaku konsumen termasuk perilaku penggunaan produk teknologi. Jika dilihat dari beberapa hasil penelitian empiris terdahulu, penerapan teori perilaku terencana dapat memprediksi perilaku konsumen dalam konteks penggunaan teknologi (lihat Cheng dan Huang, 2013; Rahman et al., 2017; Lee, 2009; Yang dan Zhou, 2011).

Beberapa waktu belakang, TPB adalah salah satu model yang diadopsi secara luas untuk mengeksplorasi perilaku individu (Cheng dan Huang, 2013). Hal ini dikarenakan dalam konsep TPB telah mengasumsikan bahwa niat untuk melakukan berbagai jenis perilaku dapat dilihat secara keseluruhan dari norma, kontrol perilaku dan sikap (Yang dan Zhou, 2011). Pada dasarnya, TPB adalah teori yang menunjukkan bahwa adanya mekanisme yang terbentuk dalam menentukan niat dan perilaku seseorang. Sebagaimana (Ajzen 1991) yang mengatakan bahwa TPB dapat menjelaskan adanya peran norma subjektif, kontrol perilaku yang dipersepsikan, dan sikap, dimana ketiganya ini dapat mempengaruhi niat, yang pada gilirannya mempengaruhi perilaku seseorang di masa depan seperti membeli atau menggunakan produk dan layanan. Berdasarkan penjelasan tersebut, maka kami menggunakan teori TPB sebagai dasar dalam mengukur niat untuk melakukan pembelian atau pengunaan aplikasi dan permainan daring freemium versi berbayar. 


\section{TINJAUAN PUSTAKA}

\section{APLIKASI FREEMIUM}

Freemium dianggap sebagai model bisnis yang relatif baru untuk layanan aplikasi dan permainan daring, dimana pengembangan teknologinya dapat dikatakan hampir sama dengan yang telah ada sebelumnya (Hamari et al., 2017). Freemium adalah model bisnis yang diciptakan sebagai kombinasi dari kata-kata free dan premium (Sato, 2019). Jika dilihat dari jenis layanannya, strategi freemium ini banyak digunakan dalam menawarkan produk atau layanan berbasis digital, termasuk perangkat lunak, permainan, dan situs web (Liu et al., 2014). Hal itu dikarenakan mengembangkan layanan baik dalam bentuk aplikasi maupun permainan daring relatif murah dan mudah sehingga beberapa perusahaan mulai mengembangkan teknologi tersebut untuk ponsel pintar (Hamari et al., 2017).

Di pasar aplikasi ponsel pintar, aplikasi dan permainan daring freemium secara gratis dapat diunduh. Namun, biasanya menyertakan penawaran untuk meningkatkan ke versi berbayar, yang bebas iklan atau memiliki fitur dan akses yang tidak terbatas. Untuk mendorong pengguna dalam membeli konten atau layanan tambahan dalam aplikasi yaitu, pembelian dalam aplikasi atau juga untuk mendorong pengguna untuk mau menambah atribut dalam permainannya, penyedia biasanya memberikan stimulus dalam paket uji coba. Sebagaimana Liu et al. (2014) yang mengatakan bahwa aplikasi gratis sering kali dicantumkan berdampingan dengan aplikasi berbayar untuk memberikan pilihan dan kesempatan kepada konsumen untuk menguji menjalankan aplikasi sebelum membeli (Liu et al., 2014).

Namun, Sato (2019) mengatakan bahwa ada trade-off ketika perusahaan menawarkan layanan dalam bentuk dua jenis layanan secara sekaligus. Jika dilihat dari sudut pandang operator layanan freemium, layanan versi premium adalah sumber pendapatan utama. Sedangkan, versi gratis adalah untuk menarik basis pengguna yang lebih besar dan mengarahkan pelanggan tersebut untuk menjadi pelanggan premium (Mäntymäki et al., 2020). Berdasarkan pembagian tersebut, terdapat dua kelompok pelanggan dengan standar pengalaman pengguna yang berbeda. Pertama, pelanggan yang menggunakan layanan versi tidak berbayar, dan kedua adalah pelanggan yang menggunakan versi premium atau berbayar (Mäntymäki et al., 2020). Berdasarkan penjelasan tersebut, kami menyimpulkan bahwa pelanggan dapat menggunakan aplikasi versi tidak berbayar atau membeli aplikasi berbayar secara langsung tanpa mencoba versi tidak berbayar.

\section{TEORI PERILAKU TERENCANA (TPB)}

Jika dilihat dari perkembangannya, TPB adalah model yang dikembangkan dari model Theory of Reasoned Action (TRA). Dalam model TRA diasumsikan bahwa perilaku aktual seseorang dalam melakukan suatu tindakan dilatarbelakangi oleh niat 
dalam berperilaku, dimana oleh norma subjektif dan sikap berperan pula terhadap perilaku tersebut (Liao et al., 2007). Namun, menurut Ajzen (1991), TRA memiliki batasan model ketika berhadapan dengan perilaku dimana seseorang memiliki kontrol kemauan yang tidak lengkap. Oleh karena itu, Ajzen pada 1991 kembali mengembangkan kembali model tersebut dengan menambahkan kontrol perilaku persepsian, yang berpotensi memiliki efek langsung pada niat perilaku.

Dalam model TPB, terdapat tiga faktor utama yang dapat mempengaruhi niat yaitu kontrol perilaku persepsian, norma subjektif, dan sikap perilaku (lihat Liou et al., 2007; Cheng dan Huang, 2013; Yang dan Zhou, 2011). Sikap mengacu pada tingkat evaluasi atau penilaian yang disukai atau tidak disukai seseorang dari perilaku yang akan dilakukan (Fishbein dan Ajzen, 1975). Sedangkan, norma subjektif diartikan sebagai tekanan sosial mengenai keyakinan normatif tentang harapan orang lain yang dirasakan oleh seseorang untuk melakukan atau tidak melakukan suatu tindakan (Ajzen, 1991; Liou et al., 2007).

Kontrol perilaku persepsian yang dirasakan diartikan sebagai persepsi sesorang tentang kemudahan atau kesulitan dalam melakukan perilaku yang diinginkan (Liou et al., 2007). Hal tersebut terkait dengan keyakinan tentang adanya faktor kontrol yang dapat memfasilitasi atau menghambat seseorang untuk berperilaku (Ajzen, 2002). Dengan demikian, keyakinan kontrol tentang sumber daya dan peluang dapat dikaitkan dengan keyakinan akan dapat menggunakan sebuah produk. Sedangkan, niat perilaku adalah ukuran dari kemauan seseorang untuk mencoba saat melakukan perilaku tertentu (Ajzen, 1991).

Faktor-faktor yang dijelaskan sebelumnya dapat dijadikan sebagai indikasi seberapa keras orang mau mencoba dan seberapa banyak upaya yang akan mereka rencanakan untuk melakukan sesuatu, yang lalu berakhir pada melakukan perilaku tersebut Ajzen (1991). Pendapat ini didukung oleh Wu dan Chen (2005) yang mengatakan bahwa dalam TPB, perilaku seseorang dalam melakukan sebuah tindakan didorong oleh niat, sikap, norma subjektif, dan kontrol perilaku yang dirasakan. Niat berperilaku adalah ukuran dari seberapa besar kesediaan seseorang untuk mencoba dan mengerahkan saat melakukan perilaku tertentu. Jika dianalogikan, semakin kuat niat seseorang untuk terlibat dalam perilaku, maka akan semakin besar seseorang untuk melakukan sebuah perilaku (Ajzen, 1991). Jadi pada model TPB, niat diasumsikan untuk menangkap faktor motivasi yang akan mempengaruhi perilaku seseorang.

\section{PENGEMBANGAN HIPOTESIS}

Jika merujuk pada konsep model TPB, terdapat tiga antesenden yang dapat mempengaruhi niat seseorang untuk melakukan sesuatu, yaitu norma subjektif, kontrol perilaku persepsian, dan sikap. Jika dijelaskan dalam bentuk mekanisme, 
stabilitas perilaku dari waktu ke waktu berhubungan dengan stabilitas niat dan kontrol perilaku yang dirasakan oleh seseorang. Faktor-faktor ini dapat menentukan bagaimana perilaku di masa lalu, dan jika tidak berubah akan menghasilkan perilaku yang sesuai di masa depan (Bamberg et al., 2003).

Sikap adalah evaluasi keseluruhan seseorang dalam melakukan perilaku (Yang dan Zhou, 2011). Pada konteks penggunaan aplikasi dan permainan daring ini, sebelum seseorang berniat untuk membeli atau menggunakan aplikasi dan permainan daring freemium versi berbayar, maka seseorang tersebut akan mengevaluasi dan menentukan sikap mereka terlebih dahulu. Beberapa penelitian empiris menemukan bahwa sikap terhadap evaluasi sebelum menggunakan produk mempengaruhi niat seseorang untuk menggunakan sebuah produk (lihat Hunsinger dan Corley, 2013; Bamberg et al., 2003; Smith et al., 2007). Hunsinger dan Corley (2013) menemukan bahwa sikap terhadap perilaku secara positif mempengaruhi niat untuk menggunakan Dropbox. Lebih lanjut, Hansen et al. (2018) juga menemukan bahwa sikap positif mempengaruhi niat dalam melakukan transaksi melalui jejaring sosial. Dalam penelitian Bamberg et al. (2003), sikap juga positif mempengaruhi niat siswa untuk naik bus ke kampus. Lebih lanjut, Smith et al. (2007) menemukan bahwa sikap memprediksi niat untuk membeli sebuah produk. Berdasarkan penjelasan tersebut, maka kami menyimpulkan bahwa:

Hipotesis 1: Sikap berpengaruh positif pada niat menggunakan aplikasi dan permainan daring freemium versi berbayar.

Di sisi lain, dalam konsep TPB terdapat antesenden yang juga menjadi pendorong terbentuknya sikap dan niat. Dalam TPB, norma subjektif berfungsi mempengaruhi sikap dan niat seseorang untuk menggunakan sebuah produk. Jika merujuk pada beberapa hasil empiris, Yang dan Zhou (2011) menemukan bahwa pada konteks anak muda di Amerika, norma subjektif secara positif mempengaruhi sikap terhadap penyampaian pesan elektronik. Lebih lanjut, penelitian Hunsinger dan Corley (2013) juga menemukan bahwa norma subjektif berkorelasi positif dengan niat untuk menggunakan Dropbox. Liao et al. (2007) menemukan bahwa norma subjektif secara positif mendorong niat perilaku terhadap penggunaan layanan daring. Smith et al. (2007) menemukan bahwa norma subjektif positif mempengaruhi niat untuk membeli produk.

Namun, disisi lain norma subjektif juga dapat mempengaruhi sikap dan kontrol perilaku persepsian. Pada konteks penggunaan aplikasi dan permainan daring, sebelum seseorang berniat untuk membeli atau menggunakan aplikasi dan permainan daring freemium versi berbayar, maka seseorang tersebut akan mempertimbangkan persepsi orang terdekat mereka mengenai pandangan mereka terhadap penggunaan aplikasi dan permainan daring freemium tersebut. Jika dilihat dari sudut pandang empiris, Yang dan Zhou (2011) menemukan bahwa pada konteks anak muda di 
Amerika, norma subjektif positif mempengaruhi kontrol perilaku persepsian. Selain itu, norma subjektif juga dapat mempengaruhi secara positif pada niat untuk meneruskan pesan elektronik. Berdasarkan penjelasan tersebut, maka kami menyimpulkan bahwa:

Hipotesis 2: Norma subjektif berpengaruh positif pada sikap menggunakan aplikasi dan permainan daring freemium versi berbayar.

Hipotesis 3: Norma subjektif berpengaruh positif pada kontrol perilaku persepsian menggunakan aplikasi dan permainan daring freemium versi berbayar.

Hipotesis 4: Norma subjektif berpengaruh positif pada niat menggunakan aplikasi dan permainan daring freemium versi berbayar.

Dalam model TPB, kontrol perilaku persepsian pada dasarnya dapat mempengaruhi niat secara tidak langsung lewat sikap dan juga dapat memprediksi niat secara langsung. Kontrol perilaku persepsian memiliki pengaruh langsung pada perilaku aktual serta pengaruh tidak langsung melalui niat perilaku (Taherdoost, 2018). Yang dan Zhou (2011) menemukan bahwa pada konteks anak muda di Amerika, kontrol perilaku persepsian secara positif mempengaruhi sikap terhadap penyampaian pesan elektronik. Ketika seseorang yakin akan mampu melakukan kontrol perilaku pada penggunaan sebuah produk, maka seseorang itu akan yakin dapat menggunakan produk tersebut.

Selain itu, Liao et al. (2007) menemukan bahwa kontrol perilaku yang dirasakan menjadi salah satu yang mendorong niat perilaku terhadap penggunaan pada layanan daring. Lebih lanjut, beberapa penelitian menemukan bahwa kontrol perilaku persepsian dapat positif mempengaruhi niat (lihat Bamberg et al., 2003; Hansen et al., 2018). Bamberg et al. (2003) dalam penelitiannya menemukan bahwa penelitian menemukan bahwa kontrol perilaku persepsian positif mempengaruhi niat para siswa untuk naik bus ke kampus. Hansen et al. (2018) menemukan bahwa kontrol perilaku persepsian secara positif mempengaruhi niat perilaku dalam melakukan transaksi melalui jejaring sosial. Selain itu, Smith et al. (2007) menemukan bahwa kontrol perilaku persepsian positif mempengaruhi niat membeli sebuah produk. Jika merujuk pada model TPB, ketika seseorang merasa mampu melakukan kontrol perilaku pada penggunaan sebuah produk, maka akan mendorong seseorang untuk menggunakan produk tersebut. Berdasarkan penjelasan tersebut, maka kami menyimpulkan bahwa:

Hipotesis 5: kontrol perilaku persepsian berpengaruh positif pada sikap menggunakan aplikasi dan permainan daring freemium versi berbayar.

Hipotesis 6: Kontrol perilaku persepsian berpengaruh positif pada niat menggunakan aplikasi dan permainan daring freemium versi berbayar. 


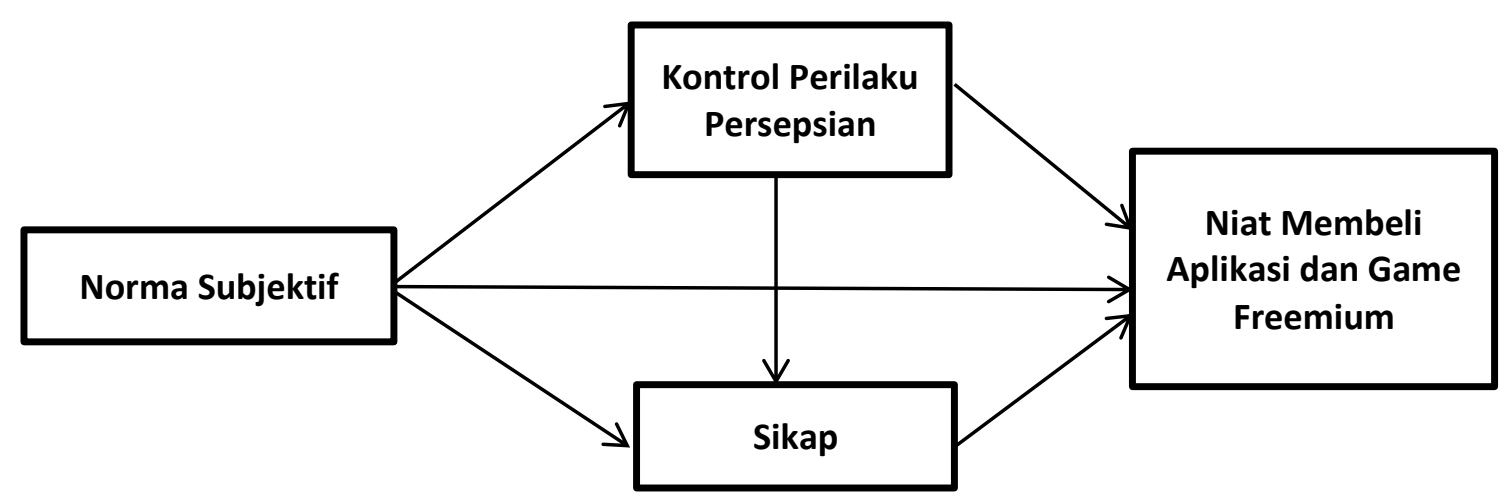

GAMBAR 1. KERANGKA PENELITIAN

\section{METODE PENELITIAN}

\section{PENETAPAN SAMPEL DAN PENGUMPULAN DATA}

Pada penelitian ini, metode penetapan sampel penelitian menggunakan purposive sampling, dimana kami menetapkan beberapa kriteria pada sampel, seperti pengguna aplikasi dan permainan daring versi gratis yang belum melakukan pembelian pada aplikasi dan permainan daring freemium versi berbayar dalam kurun waktu 6 bulan sebelumnya. Sedangkan, pengumpulan data dilakukan dengan menggunakan metode survei daring. Survei daring dilakukan dengan cara menyebarkan kuesioner pada beberapa media sosial untuk mendapat target ukuran sampel yang telah ditentukan. Berdasarkan hasil pengumpulan data, terdapat 225 responden yang berpartisipasi mengisi kuesioner. Namun, dari 225 data responden yang ada, hanya 189 data responden yang dapat dianalisis.

\section{PENGUKURAN}

Untuk menghasilkan item pengukuran yang sesuai dengan konteks penelitian, maka kami melakukan translasi dan modifikasi agar pengukuran dapat digunakan sesuai konteks penelitian ini. Pada model TPB, kami menggunakan pengukuran dari beberapa peneliti terdahulu, yang terdiri dari sikap (Cheng et al., 2006), norma subyektif (Wu dan Chen, 2005), kontrol perilaku persepsian (Wu dan Chen, 2005), dan niat (Cheng et al., 2006). Lebih lanjut, untuk mengukur persepsi pada setiap responden, maka setiap item pengukuran diukur menggunakan skala Likerts 5 poin, dengan pilihan jawaban mulai dari sangat tidak setuju (1) hingga sangat setuju (5). Kami juga memasukkan beberapa pertanyaan demografis, seperti jenis kelamin, usia, dan lama waktu menggunakan aplikasi atau permainan daring freemium. 


\section{HASIL PENELITIAN}

Dalam melakukan analisis data, kami menggunakan SPSS untuk melakukan analisis deskriptif pada responden. Berdasarkan hasil analisis deskriptif pada Tabel 1, diketahui bahwa dari 189 responden yang berpartisipasi dalam survei kami ditemukan bahwa 63 responden dengan persentase adalah berjenis kelamin laki-laki dan 126 perempuan dengan persentase 67 persen. Responden mayoritas berusia 15-20 tahun dengan persentase 68,8 persen. Sedangkan, mayoritas responden menggunakan aplikasi atau permainan daring freemium versi tidak berbayar adalah lebih dari 5 bulan dengan persentase 47 persen. Hasil analisis karakteristik responden disajikan pada Tabel 1.

Tabel 1. Karakteristik Responden

\begin{tabular}{cccc}
\hline Variabel & Kategori & Frekuensi & $\%$ \\
\hline Jenis Kelamin & Laki-laki & 63 & 33 \\
Usia & Perempuan & 126 & 67 \\
& $15-20$ Tahun & 131 & 68,8 \\
& $21-25$ Tahun & 55 & 28,8 \\
& $26-30$ Tahun & 1 & 0,5 \\
Aplikasi atau Permainan & $31-35$ Tahun & 2 & 1 \\
daring Freemium versi tidak & 1 Bulan & 61 & 31,9 \\
berbayar & & & \\
& & 21 & 11 \\
& 3 Bulan & 10 & 5,2 \\
& 5 Bulan & 89 & 46,6 \\
\hline
\end{tabular}

Sumber: Data Primer (2020)

Selanjutnya, untuk menganalisis model penelitian, kami menggunakan persamaan struktural (SEM) dengan menggunakan Amos. Pada tahap analisis ini, pertama kami melakukan analisis faktor konfirmatori (CFA) untuk menguji model pengukuran sebelum menguji model struktural. Berdasarkan hasil analisis CFA, setiap item pengukuran menunjukkan nilai faktor loading diatas 0,60. Lebih lanjut, rerata varian yang diekstraksi (AVE) untuk setiap konstruksi memiliki nilai yang berkisar antara 0,51 hingga 0,61 atau lebih dari 0,5. Hal ini menunjukkan bahwa pengukuran yang digunakan juga memiliki validitas diskriminan dan konvergen yang baik (Bagozzi dan Yi, 1988). 
Lebih lanjut, pada uji reliabilitas, kami menggunakan analisis reliabilitas komposit dan Cronbach Alpha. Berdasarkan hasil analisis, nilai dari reliabilitas komposit berkisar antara 0,71 hingga 0,83. Sedangkan, nilai Cronbach Alpha berkisar antara $0,81-0,83$. Hal ini menandakan bahwa nilai dari reliabilitas komposit (CR) dan Cronbach Alpha lebih dari 0,7 , sehingga dapat disimpulkan bahwa pengukuran yang digunakan memiliki reliabilitas yang baik (Bagozzi dan Yi, 1988). Hasil analisis validitas dan reliabilitas disajikan pada Tabel 2 .

Tabel 2. Hasil Validitas dan Reliabilitas

\begin{tabular}{lcccc}
\hline \multicolumn{1}{c}{ Indikator } & Loading $(\boldsymbol{\lambda})$ & Cronbach Alpha & CR & AVE \\
\hline Subjektif Norm 1 & 0,75 & 0,81 & & \\
Subjektif Norm 2 & 0,82 & 0,82 & & \\
Subjektif Norm 3 & 0,77 & 0,82 & 0,83 & 0,61 \\
Kontrol Perilaku Persepsian 1 & 0,76 & 0,82 & & \\
Kontrol Perilaku Persepsian 2 & 0,72 & 0,83 & 0,71 & 0,55 \\
Slkap 1 & 0,70 & 0,82 & & \\
Slkap 2 & 0,80 & 0,82 & 0,72 & 0,57 \\
Niat 1 & 0,62 & 0,82 & & \\
Niat 2 & 0,89 & 0,82 & & \\
Niat 3 & 0,76 & 0,83 & 0,81 & 0,59 \\
\hline \multicolumn{1}{c}{ Sumber: } & & & &
\end{tabular}

Sumber: Data Primer (2020)

Setelah itu, kami melakukan pengujian Goodness Of Fit atau uji kesesuaian pada model yang kami gunakan. kami melakukan beberapa modifikasi agar sesuai dengan seluruh model, sehingga nilai aktual Goodness Of Fit indeks yang tercantum berada diatas ambang batas nilai yang direkomendasikan. Berdasarkan hasil uji kesesuaian pada Tabel 3, ditemukan bahwa (X2 /df = 1,169, $G F I=0,953, R M S E A=0,60$, $A G F I=0,911, T L I=0,953, N F I=0,929, C F I=0,970)$. Jadi dapat disimpulkan bahwa model yang kami gunakan memenuhi kriteria dari uji kesesuaian dan dapat dilanjutkan pada analisis model struktural. Hasil analisis uji kesesuaian disajikan pada Tabel 3.

Tabel 3. Hasil Analisis Uji Kesesuaian

\begin{tabular}{cccc}
\hline GOF & Hasil Analisis & Cut-Off Value & Status \\
\hline Chi Square & 41.5 & Diharapkan kecil & baik \\
Significance Probability & 0,00 & $\geq 0,05$ & Baik \\
CMIN/DF & 1,169 & $\leq 2,0$ & Baik \\
GFI & 0,953 & $\geq 0,80$ & Baik \\
RMSEA & 0,60 & $\leq 0,80$ & Baik \\
AGFI & 0,911 & $\geq 0,80$ & Baik \\
TLI & 0,953 & $\geq 0,90$ & Baik \\
NFI & 0,929 & $\geq 0,90$ & Baik \\
CFI & 0,970 & $\geq 0,90$ & Baik \\
\hline
\end{tabular}

Sumber: Data Primer (2020) 
Setelah melakukan uji kesesuaian pada model yang digunakan. Kami melakukan analisis model struktural. Berdasarkan hasil analisis model struktural ditemukan bahwa nilai $C R$ antara variabel sikap pada niat adalah 1,137 dengan signifikansi 0,181, maka hipotesis 1 ditolak. Lebih lanjut, nilai $C R$ antara variabel norma subjektif pada sikap adalah 4,725 dengan signifikansi 0,00, maka hipotesis 2 diterima. Sedangkan, nilai $C R$ antara variabel norma subjektif pada kontrol perilaku persepsian adalah 4,982 dengan signifikansi 0,00, maka hipotesis 3 diterima. Lebih lanjut, nilai $C R$ antara variabel norma subjektif pada niat adalah 0,467 dengan signifikansi 0,640, maka hipotesis 4 ditolak. Nilai $C R$ antara variabel kontrol perilaku persepsian pada sikap adalah 1,113 dengan signifikansi 0,226, maka hipotesis 5 ditolak. Lebih lanjut, nilai $C R$ antara variabel kontrol perilaku persepsian pada niat adalah 2,905 dengan signifikansi 0,04, maka hipotesis 6 diterima. Jadi, berdasarkan hasil analisis hanya ada 3 hipotesis yang diterima, yaitu hipotesis 2, 3, dan 6. Hasil analisis struktural SEM disajikan pada Tabel 4.

Tabel 4. Hasil Analisis Struktural SEM

\begin{tabular}{|c|c|c|c|c|}
\hline Hubungan Struktural & Beta & $\begin{array}{c}\text { The } \\
\text { unstandardized } \\
\text { Weights } \\
\text { CR }\end{array}$ & $\begin{array}{c}P \text { - } \\
\text { value }\end{array}$ & Hipotesis \\
\hline Sikap ->Niat & 0,144 & 1,137 & 0,181 & Hipotesis 1 ditolak \\
\hline Norma Subjektif -> Sikap & 0,537 & 4,725 & 0,00 & $\begin{array}{l}\text { Hipotesis } 2 \\
\text { diterima }\end{array}$ \\
\hline $\begin{array}{l}\text { Norma Subjektif -> Kontrol Perilaku } \\
\text { Persepsian }\end{array}$ & 0.381 & 4,982 & 0,00 & $\begin{array}{l}\text { Hipotesis } 3 \\
\text { diterima }\end{array}$ \\
\hline Norma Subjektif -> Niat & 0,046 & 0,467 & 0,640 & Hipotesis 4 ditolak \\
\hline Kontrol Perilaku Persepsian -> Sikap & 0,184 & 1,113 & 0,226 & Hipotesis 5 ditolak \\
\hline Kontrol Perilaku Persepsian -> Niat & 0,397 & 2,905 & 0,04 & $\begin{array}{l}\text { Hipotesis } 6 \\
\text { diterima }\end{array}$ \\
\hline
\end{tabular}

Sumber: Data Primer (2020)

\section{PEMBAHASAN}

Tujuan penelitian ini adalah untuk menguji niat pengguna aplikasi dan permainan daring freemium versi tidak berbayar berpindah menggunakan aplikasi dan permainan daring freemium versi berbayar. Untuk menguji fenomena ini, kami menggunakan model TPB sebagai dasar teori. Berdasarkan hasil pengujian, kami menemukan beberapa temuan baru mengenai antesenden niat penggunaan aplikasi dan permainan daring freemium versi berbayar. Berdasarkan hasil analisis, kami menemukan bahwa norma subjektif berpengaruh positif pada sikap dan kontrol perilaku persepsian dalam menggunakan aplikasi dan permainan daring freemium 
versi berbayar. Hal ini sesuai dengan penelitian yang dilakukan oleh Yang dan Zhou (2011). Selain itu, kami juga menemukan bahwa kontrol perilaku persepsian berpengaruh positif pada niat menggunakan aplikasi dan permainan daring freemium versi berbayar. Hal ini sejalan dengan hasil penelitian terdahulu yang menemukan bahwa kontrol perilaku persepsian menjadi salah satu yang mendorong niat perilaku (Bamberg et al., 2003; Hansen et al., 2018; Liao et al., 2007; Septian et al., 2020; Smith et al., 2007). Berdasarkan hasil ini, kami berasumsi bahwa ketika seseorang merasakan atau memiliki norma subjektif yang positif, maka seseorang yang belum menggunakan aplikasi atau permainan daring versi tidak berbayar akan cenderung memiliki sikap dan kontrol perilaku atas penggunaan aplikasi atau permainan daring freemium versi berbayar. Lalu, ketika seseorang merasa memiliki kontrol perilaku, maka seseorang itu cenderung memiliki niat beralih untuk menggunakan aplikasi atau permainan daring freemium versi berbayar.

Namun, hasil pengujian sikap pada niat, norma subjektif pada niat, kontrol perilaku persepsian pada sikap penggunaan aplikasi, dan permainan daring freemium versi berbayar tidak terbukti secara signfikan. Jika merujuk pada penelitian terdahulu, norma subjektif, kontrol perilaku persepsian dan sikap pada dasarnya dapat mempengaruhi niat secara tidak langsung lewat sikap dan juga dapat memprediksi niat secara langsung (lihat Taherdoost, 2018; Bamberg et al., 2003). Berdasarkan hasil tersebut, kami menyimpulkan bahwa hubungan norma subjektif, kontrol perilaku persepsian, dan sikap terhadap niat memiliki hubungan pemediasian. Hal ini mungkin dapat mempengaruhi hasil dari hubungan norma subjektif, kontrol perilaku persepsian, dan sikap terhadap niat pada penelitian ini.

\section{KESIMPULAN DAN SARAN}

Berdasarkan hasil pengujian, kami menyimpulkan beberapa temuan. Pertama, norma subjektif memiliki pengaruh positif pada sikap dan kontrol perilaku persepsian. Selanjutnya, kontrol perilaku persepsian memiliki pengaruh positif pada niat menggunakan aplikasi atau permainan daring freemium versi berbayar. Hal mengindikasikan bahwa norma subjektif, dan kontrol perilaku persepsian dapat mendorong niat dalam penggunaan aplikasi atau permainan daring freemium versi berbayar. Kedua, sikap terbukti berpengaruh tidak signifikan pada niat. Hal ini dikarenakan adanya mekanisme hubungan mediasi antara variabel tersebut yang belum kami uji, sehingga mempengaruhi hasil penelitian ini. Ketiga, berdasarkan hasil analisis yang telah dilakukan, kami menyimpulkan bahwa model TPB dapat digeneralisasi pada konteks penelitian ini, karena memiliki akurasi model untuk memprediksi dan menjelaskan niat perilaku penggunaan aplikasi atau permainan daring freemium versi berbayar. Disisi lain, terdapat beberapa teori dasar dan variabel 
yang dapat dihubungkan pada model TPB ini, seperti model Technology Acceptence Model, risiko persepsian, dan kepuasan.

\section{DAFTAR PUSTAKA}

Ajzen, I. (1991). The theory of planned behavior. Organizational behavior and human decision processes, 50(2), 179-211.

Ajzen, I. (2002). Perceived behavioral control, self-efficacy, locus of control, and the theory of planned behavior 1. Journal of applied social psychology, 32(4), 665683.

Bagozzi, R. P., \& Yi, Y. (1988). On the evaluation of structural equation models. Journal of the academy of marketing science, 16(1), 74-94.

Bamberg, S., Ajzen, I., \& Schmidt, P. (2003). Choice of travel mode in the theory of planned behavior: The roles of past behavior, habit, and reasoned action. Basic and applied social psychology, 25(3), 175-187.

Cheng, H. H., \& Huang, S. W. (2013). Exploring antecedents and consequence of online group-buying intention: An extended perspective on theory of planned behavior. International Journal of Information Management, 33(1), 185-198.

Cheng, S., Lam, T., \& Hsu, C. H. (2006). Negative word-of-mouth communication intention: An application of the theory of planned behavior. Journal of Hospitality \& Tourism Research, 30(1), 95-116.

Fishbein, M., \& Ajzen, I. (1975). Belief. Attitude, Intention and Behavior: An Introduction to Theory and Research, 578.

Hansen, J. M., Saridakis, G., \& Benson, V. (2018). Risk, trust, and the interaction of perceived ease of use and behavioral control in predicting consumers' use of social media for transactions. Computers in Human Behavior, 80, 197-206.

Hamari, J., Hanner, N., \& Koivisto, J. (2017). Service quality explains why people use freemium services but not if they go premium: An empirical study in free-toplay games. International Journal of Information Management, 37(1), 14491459.

Hunsinger, D. S., \& Corley, J. K. (2013). What Influences Students to Use Dropbox?. Cloud Computing.

Hsu, C. L., \& Lin, J. C. C. (2015). What drives purchase intention for paid mobile apps?An expectation confirmation model with perceived value. Electronic Commerce Research and Applications, 14(1), 46-57.

Ladeira, W. J., de Santini, F. O., Sampaio, C. H., \& Araujo, C. F. (2016). Experiential value and domain-specific innovativeness during freemium game usage: effects on child well-being. Young Consumers. 
Lee, M. C. (2009). Factors influencing the adoption of internet banking: An integration of TAM and TPB with perceived risk and perceived benefit. Electronic commerce research and applications, 8(3), 130-141.

Liao, C., Chen, J. L., \& Yen, D. C. (2007). Theory of planning behavior (TPB) and customer satisfaction in the continued use of e-service: An integrated model. Computers in human behavior, 23(6), 2804-2822.

Liu, C. Z., Au, Y. A., \& Choi, H. S. (2014). Effects of freemium strategy in the mobile app market: An empirical study of google play. Journal of Management Information Systems, 31(3), 326-354.

Mäntymäki, M., Islam, A. N., \& Benbasat, I. (2020). What drives subscribing to premium in freemium services? A consumer value-based view of differences between upgrading to and staying with premium. Information Systems Journal, 30(2), 295-333.

Rahman, M. M., Lesch, M. F., Horrey, W. J., \& Strawderman, L. (2017). Assessing the utility of TAM, TPB, and UTAUT for advanced driver assistance systems. Accident Analysis \& Prevention, 108, 361-373.

Sato, S. (2019). Freemium as optimal menu pricing. International Journal of Industrial Organization, 63, 480-510.

Septiana, I., Salim, M., Daulay, M.Y.I. (2020). Analysis The Effect Of Habit And Perceived Enjoyment Mediated By Behavioural Intention To Adoption On Students Using Mobile Banking BNI. Managament Insight: Jurnal IImiah Manajemen. 15(1), 78-94

Smith, J. R., Terry, D. J., Manstead, A. S., Louis, W. R., Kotterman, D., \& Wolfs, J. (2007). Interaction effects in the theory of planned behavior: The interplay of selfidentity and past behavior. Journal of Applied Social Psychology, 37(11), 27262750.

Taherdoost, H. (2018). A review of technology acceptance and adoption models and theories. Procedia manufacturing, 22, 960-967.

Wu, L., \& Chen, J. L. (2005). An extension of trust and TAM model with TPB in the initial adoption of on-line tax: an empirical study. International Journal of HumanComputer Studies, 62(6), 784-808.

Yang, H. C., \& Zhou, L. (2011). Extending TPB and TAM to mobile viral marketing: An exploratory study on American young consumers' mobile viral marketing attitude, intent and behavior. Journal of Targeting, Measurement and Analysis for Marketing, 19(2), 85-98. 